\title{
Bacterial Pathogens in Cattle Egret (Bubulcus ibis) and Pied Crow (Corvus albus) in Kinshasa, Democratic Republic of the Congo
}

\author{
Kisasa K. Robert ${ }^{*}$, Nduaya N. Clarisse1, Kafuti Chadrack1, Ekumbo Babby ${ }^{1}$, Ngandu Michel1, \\ Liesse Jean Marie'2, Mbundu L. Cyprien² \\ ${ }^{1}$ Ornithological Research Unit of the Department of Biology, Faculty of Science, University of Kinshasa, Kinshasa, \\ Democratic Republic of Congo \\ ${ }^{2}$ Experimental and Pharmaceutical Microbiology Laboratory, Faculty of Pharmaceutical Sciences, University of Kinshasa, \\ Kinshasa, Democratic Republic of Congo \\ Email: ^bob.kisasa@unikin.ac.cd
}

How to cite this paper: Robert, K.K., Clarisse, N.N., Chadrack, K., Babby, E., Michel, N., Marie, L.J. and Cyprien, M.L. (2021) Bacterial Pathogens in Cattle Egret (Bubulcus ibis) and Pied Crow (Corvus albus) in Kinshasa, Democratic Republic of the Congo. Open Access Library Journal, 8: e7353.

https://doi.org/10.4236/oalib.1107353

Received: March 26, 2021

Accepted: April 17, 2021

Published: April 20, 2021

Copyright $\odot 2021$ by author(s) and Open Access Library Inc.

This work is licensed under the Creative Commons Attribution International License (CC BY 4.0).

http://creativecommons.org/licenses/by/4.0/

\begin{abstract}
Purpose: Our study focused on Pied Grow and Cattle Egret, two commensal and ubiquitous birds feeding in dumps and frequenting our homes. Our aim was to identify the bacteria that birds bring to our homes and could be a potential risk to Congolese health. Method: We have done bacteriological analyses of bird feces for to explore its gut microbiota composition. The feces were collected in the uricotelic cloaca by using a swab in 52 Cattle Egrets (Bubulcus ibis) and 23 Pied Crows (Corvus albus) captured from January 2019 to January 2020 in the same dumps from the city of Kinshasa. Results: The findings reveal the presence of following microorganisms, namely Proteus vulgaris, Klebsiella pneumoniae, Salmonella sp., Pseudomonas aeruginosa, Citrobacter spp, Escherichia coli in the feces of birds. It should be noted that these birds are contaminated when they frequent and feed in landfills around our residences or hospitals. The bacterial composition of the intestinal flora estimated from feces is different from one bird to another and from the bird species to another in the same catch site. Conclusion: Commensal birds constitute the potential sources of infectious diseases transmission if hygienic conditions are not respected, including the regular disposal and treatment of waste in the city. Molecular studies are required in order to determine the antibiotic resistance gene of these microorganisms and the impact of these bacteria on avian diversity in this region.
\end{abstract}

\section{Subject Areas}

Microbiology 


\section{Keywords}

Cattle Egret, Pied Crow, Microbiota, Dumps, Kinshasa

\section{Introduction}

In Kinshasa, the capital of the Democratic Republic of Congo (DRC), recent studies by Punga and Ifuta (Kisasa and Aloni, 2011 [1]; Punga and Ifuta, 2015 [2]) documented about 131 species of birds grouped into 40 families, representing $11 \%$ of species of the all country. Despite this avian diversity, rare studies carried out throughout the country concern only their systematics and habitats (Kisasa and Aloni, 2011) [1]. Information about the role of these birds in the emergence of epidemics in the region is lacking. A preliminary study by Kisasa et al. revealed the presence of lice mallophages (Phthiraptera) Myrsidea balati, Columbicola columbae and Menacanthus stramineus, Ardeicola ciconiae, Goniodes sp., Ciconiphilus decimfasciatus, Ardeicola ciconiae and Cuculiphilus sp on some birds from seven bird species of Kinshasa city (Kisasa et al. 2020) [3].

M. stramineus, in domestic hens, Gallus domesticus can cause the death of wild turkey chicks, Meleagris gallopavo (Djelil, 2012) [4]. It is also implicated in the transmission of encephalomyelitis viruses (Amir, A. (2006) [5]. The role of birds as vectors of pathogenic germs to humans has been amply documented. This is the case, for example, with some waterbirds. Potential pathogenic genera were identified in the gut microbiota of the different species, suggesting that waterbirds may disseminate pathogenic species like Clostridium, Helicobacter, Campylobacter, Vibrio, etc., between waterbodies (Laviad-Shitrit, 2019) [6].

The gut microbiota of an organism is established immediately after birth and changes due to the host life-style, diet, environmental conditions, genome, etc. (Nicholson, 2012 [7]; Sommer, 2013 [8]; Punga and Ifuta, 2015 [2]).

The aim of this study is to estimate the impact of environmental conditions on the composition of microbiota of the birds. We chose the Cattle Egret and Pied Crow, two commensal birds feeding in dumps and in our immediate environment. We hypothesized that the bacteriological composition of the gut microbiota of these two birds is a good indicator of the potential risk to public health and bacteria distribution on its hosts is random in the dumps explored.

\section{Materials and Methods}

\subsection{Study Area}

This study was conducted in five dumps of Kinshasa city, DRC: Home X (A), Home XX (B), Home Village Maluku (C), Triangle of market gardeners, and University clinics (E). The geographic data for these five dumps are presented in Table 1.

Birds have been captured in these unsanitary dumps as shown in Figure 1. 
Table 1. Geographic coordinates of five dumps.

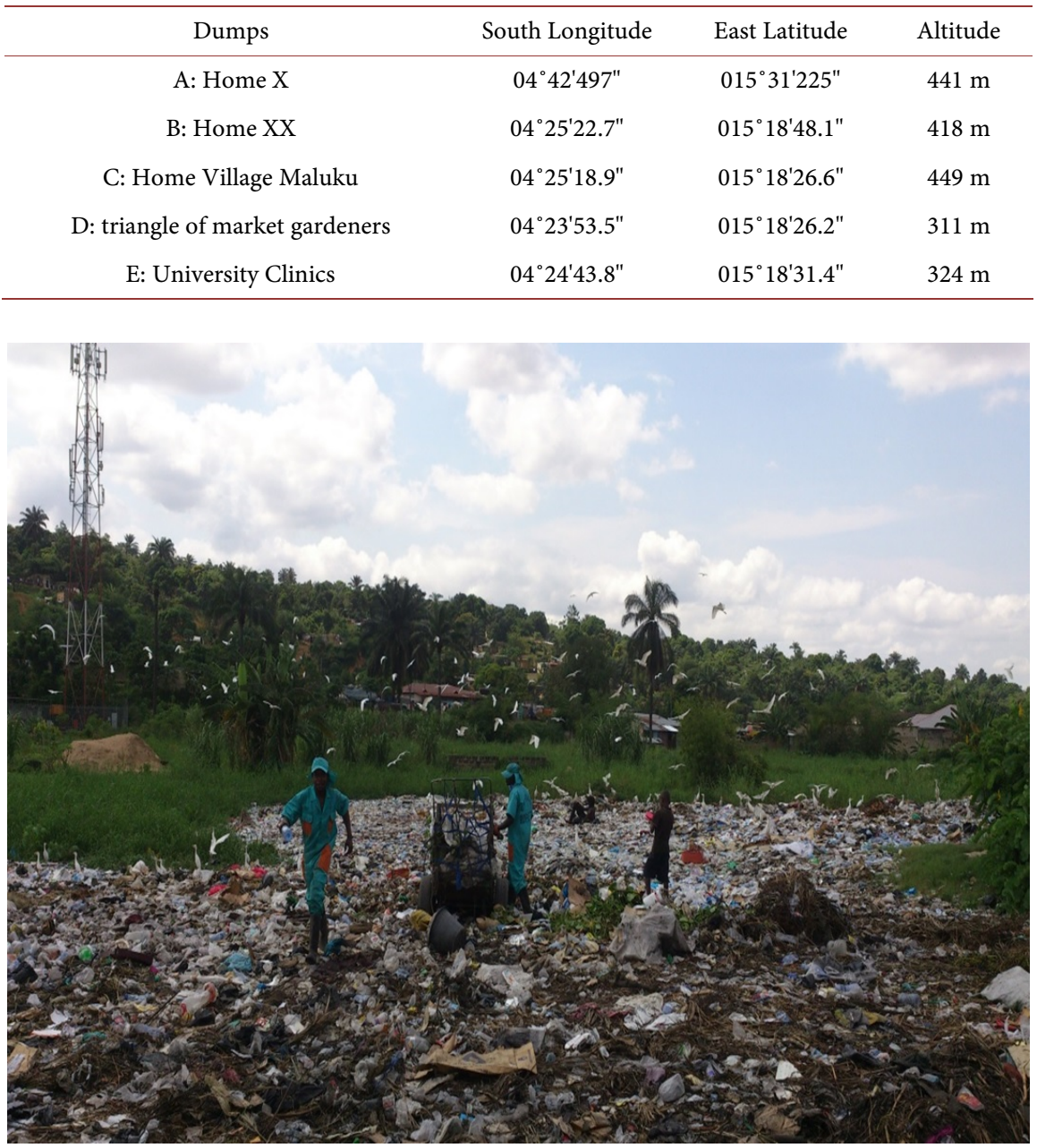

Figure 1. Triangle of market gardeners' dump (D).

\subsection{Sample Collection}

A total of 52 Cattle Egrets (Bubulcus ibis) and 23 Pied Crows (Corvus albus) were captured from January 2019 to January 2020. We used the self-made traps; a noose of nylon wire attached to a piece of wood. The birds were attracted to each trap by palm oil-soaked pouches and pieces of fish.

To collect feces, sterile cotton swabs wetted with sterile normal saline water were inserted in the cloacae of 75 birds, and placed in sterile vials. After collection of cloacal swabs, the birds were then freed. The samples were transported immediately to the laboratory in an ice box. The difference in the size of the fecal samples analyzed was related to the bird capture technique. However, at least one specimen of each bird species was captured in each dump. This did not prevent us from having a rough idea of the composition of gut microbiota of these two species of birds very close to human residences.

\subsubsection{Isolation of Microorganisms}

Swab samples were enriched in buffered peptone water at $37^{\circ} \mathrm{C}$ for $24 \mathrm{~h}$. Subse- 
quently, the cultures were streaked on MacConkey agar and incubated at $37^{\circ} \mathrm{C}$ overnight. Different single colonies were then collected and purified.

\subsubsection{Purification}

Gram negative bacilli were identified using microbiological conventional methods including Gram staining, oxidase tests, indole and urease production, citrate utilization, hydrogen sulphide, gas production and fermentation of sugars, phenylalanine deaminase, lysine decarboxylase (L.D.C.), ornithine decarboxylase (O.D.C.), arginine dihydrolase (A.D.H.) tests, nitrate reduction, casein hydrolysis, methyl red and Voges-Proskauer reactions.

\subsubsection{Identification of Microorganisms}

The identification of isolated strains involved a series of preliminary tests (macroscopic and microscopic examination) which should enable us to group the identified microorganisms into different classes, and some biochemical tests were carried out to enable the identification at the species level. (i) Macroscopic examination a. Bacteria the examination was based on the search of the following characteristics: size, color, pigmentation, shape, surface appearance, colony edge appearance, consistency and opacity (Iteku et al. 2020) [9].

\subsubsection{Microscopic Examination}

1) Fresh condition

It is a very simple examination of implementation and takes place under an optical microscope (brand HITACHI) at 40×. This allows: the observation of living bacteria and the determination of their morphology, their mode of grouping, their possible motility and the approximate quantity of bacteria (Ladraa et al. 2016) [10].

2) Gram staining

Examination of the Gram-stained smear allows the observation of any bacteria present, differentiating them into Gram positive and Gram negative according to their morphology and dye affinity. It allows also to assess their abundance, grouping, homogeneity or morphological heterogeneity (Ladraa et al. 2016) [10].

\subsubsection{Biochemical Tests}

1) Catalase test Catalase

Is an enzyme present in most strict aerobic and facultative anaerobic bacteria. It breaks down hydrogen peroxide into water and oxygen, which is released in the following reaction (Ladraa et al. 2016) [10].

$$
\mathrm{H}_{2} \mathrm{O}_{2} \rightarrow \frac{1}{2} \mathrm{O}_{2}+\mathrm{H}_{2} \mathrm{O}
$$

The release of gas bubbles indicates the presence of catalase i.e., the test is positive.

2) Classical biochemical gallery

In order to identify Enterobacteriaceae, several traits need to be studied.

1) Analysis of carbohydrates and energy metabolism 
This analysis consisted on the use of lactose and sucrose, fermentation with or without glucose gas, production of $\mathrm{H} 2 \mathrm{~S}$. Meanwhile, the use of citrate as a sole source of carbon and energy: the purpose of this test was to find out whether the bacteria use citrate as a source of carbon.

2) Analysis of protein metabolism

Here, the focus was on the production of indole (Tryptophan metabolism) and the one of bacterial decarboxylases ODC (Ornithine decarboxylase), LDC (Lysine decarboxylase and ADH (amino acid metabolism). Table 2 presents different Enterobacteriaceae identified in the feces of each commensal bird.

\section{Results and Discussion}

\subsection{Gut Composition of Cattle Egrets and Pied Crows in Kinshasa, DR. of the Congo}

A total of 75 feces, including 52 Cattle Egret and 23 Pied Crow captured in the same dumps, were subjected to bacteriological testing. The different Gram-negative bacilli identified in both bird species are shown in Table 2.

The test was positive for Eschericha coli and Citrobacter spp in all samples analyzed. However, Proteus vulgaris was found in all Cattle Egret samples except those captured in the Home X dump (site A) and in all Pied Crow samples except those from the Home X, Home XX (Site B) and Maluku Village (Site C) dumps. Klebsiella pneunomae was found only in $50 \%$ of feces of Cattle Egret captured in the triangle dump (site D) and negative in all feces of Pied Crow. The latter appear to be more parasitized than the Cattle Egret because of the additional presence of Pseudomonas aeruginosa and Salmonella spp. in samples collected from the university clinic dump (site E). The gut microbiota composition of two bird species appears different assets than sharing the same ecological niche. These results confirm the heterogeneity of each intestinal flora of each of the 75 bird species studied.

Table 2. Host-gut microbiota interaction with dumps (environmental conditions).

\begin{tabular}{|c|c|c|c|c|c|c|c|c|c|c|}
\hline \multirow{2}{*}{$\begin{array}{c}\text { Hosts } \\
\text { Gut microbiota }\end{array}$} & \multicolumn{5}{|c|}{ Bubbulcus ibis $(\mathrm{n}=52)$} & \multicolumn{5}{|c|}{ Corvus albus $(\mathrm{n}=23)$} \\
\hline & $\mathrm{A}(\mathrm{n})$ & $\mathrm{B}(\mathrm{n})$ & $\mathrm{C}(\mathrm{n})$ & $\mathrm{D}(\mathrm{n})$ & $\mathrm{E}(\mathrm{n})$ & $\mathrm{A}(\mathrm{n})$ & $\mathrm{B}$ & $\mathrm{C}(\mathrm{n})$ & $\mathrm{D}(\mathrm{n})$ & $\mathrm{E}(\mathrm{n})$ \\
\hline $\begin{array}{l}\text { E. coli (Theodor } \\
\text { Escherich, 1885) }\end{array}$ & 19 & 14 & 12 & 4 & 3 & 5 & 7 & 3 & 3 & 5 \\
\hline $\begin{array}{l}\text { Citrobacter spp (Werkman et } \\
\text { Gillen, 1932) }\end{array}$ & 19 & 14 & 12 & 4 & 3 & 5 & 7 & 3 & 3 & 5 \\
\hline $\begin{array}{l}\text { Proteus vulgaris (Gustsave } \\
\text { Hauser, 1885) }\end{array}$ & 0 & 8 & 4 & 1 & 0 & 0 & 0 & 0 & 2 & 5 \\
\hline $\begin{array}{l}\text { Klebsiella pneumonae } \\
\text { (Friedländer) }\end{array}$ & 0 & 0 & 0 & 2 & 0 & 0 & 0 & 0 & 0 & 0 \\
\hline $\begin{array}{l}\text { Pseudomonas aeruginosa } \\
\text { (Carle gessaed) }\end{array}$ & 0 & 0 & 0 & 0 & 0 & 0 & 0 & 0 & 0 & 5 \\
\hline Salmonella spp & 0 & 0 & 0 & 0 & 0 & 0 & 2 & 0 & 0 & 5 \\
\hline
\end{tabular}

Legend: $A(n), B(n), C(n), D(n), E(n)$ symbolize the number of infected birds by bacteria of the Dump A, B, C, D, E respectively. 


\subsection{Discussion}

The importance of wild birds as potential vectors of disease has received recent renewed empirical interest, especially regarding human health. Understanding the spread of bacterial pathogens in wild birds may serve as a useful model for examining the spread of other disease organisms, both amongst birds, and from birds to other taxa. Information regarding the gut microbiota is limited for the majority of wild bird species, with the few well-studied examples concentrating on bacteria that are zoonotic and/or relate to avian species of commercial interest. However, most studies are limited by small sample sizes, the frequent absence of longitudinal data, and the constraints of using selective techniques to isolate specific pathogens. The pathogenic genera found in the gut are often those suspected to exist in the birds' habitat (Benskin, 2009) [11]. In Kinshasa, the capital of the DRC, public toilets are almost non-existent, the water from the septic tanks is discharged into the streets or into urban and guttering rivers. It is in these unsanitary habitats that Cattle Egrets, Pied Crows and commensal rodents feed and are likely infected with enterobacteriaceae from the human gastrointestinal tract (Laudisoit et al. 2005 [12]; Kisasa et al. 2020) [3]. Human responsibility for the spread of pathogenic germs has been the subject of numerous studies. Recent studies by Iteku and his team (Iteku et al. 2020) [9] have shown that as a result of the exchange of contaminated currency notes between humans, microorganisms begin to spread, contributing to the spread of antibiotic resistance and many virulence factors and pose a risk to public health. The different bacteria on the currency notes have also been identified in the feces of our birds.

Bacteria contained in the feces analyzed appears to vary qualitatively from sample to sample. In the Cattle Egrets, we identified E. coli, Citrobacter $s p$ and Proteus vulgaris in all dumps except Klebsiella pneumonae found only in samples from the Maluku dump (D). However, Pied Crow appears to be the most infected. In addition to all the enterobacteriaceae identified in the Cattle Egrets, we identified Pseudomonas aeruginosa and Salmonella spp. Although sharing the same ecological niches. Nicholson et al. 2012 [7] and Sommer and Bäckhed, 2013 stipulate that due to the influence of a varied diet, genetics, hygiene level, medical treatments administered and the environment, the composition of the intestinal microbiota then develops qualitatively and quantitatively during the first few years of life. The qualitative and quantitative composition of the microbiota then remains fairly stable thereafter. Fluctuations in sex hormones-testosterone and estrogens-may nonetheless have an impact on its composition. Medical treatments (birds feeding on oates soaked in the blood of hospital patients dumped in dumps for example), changes in lifestyle and various events can also modify the microbiota, in a more or less durable manner. For instance, antibiotic treatment reduces the quality and quantity of the microbiota over several days to several weeks. The initial species are largely capable of reestablishing themselves, although differences may persist. Repeated antibiotic therapy during 
a person's life could thus lead to gradual, permanent, potentially harmful changes in the microbiota. In humans, however, we do not all appear to be equal with regard to this risk: some individuals apparently have a more stable microbiota than others, when faced with the same disruptive events. Wouldn't it also be the case in these two species of birds studied?

The presence of $E$. coli in all samples does not surprise us in the various dumps around student residential homes and markets. Indeed, the students often defecate in the nature where rains facilitate feces dissemination. This bacteria in mutualist symbiosis in mammalians and birds' colonists becomes pathogenic in the environment and responsible for the few pathologies as enteric diseases, Urinary tract infections (Hooton and Walter, 1997) [13] and Neonatal meningitis ( $\mathrm{Ku}$ et al. 2015) [14]. Molecular study is being considered to determine the pathogenic E. coli strain.

Other bacteria were more found in birds frequenting the dump of Kinshasa University Clinics (E) or nearby (Village Maluku). These are Citrobacter spp., $P$. vulgaris, Klebisiella pneumonae and Pseudomonas aeruginosa. They are responsible for various known diseases in humans such as Abdominal Sepsis, Urinary Tract Infection and Bacteremia, Brain Abscess, infection of skin and tissue (Bryan and Reynolds 1984 [15]; Akihisa et al. 1997 [16]; Doran 1999 [17]; Amir 2006 [4]; Hsiu-Lin Chen et al. 2008 [18]; Benskin et al. 2009 [11]; Djelil, 2012 [4]; Brouwer et al. 2014 [19]; Iteku et al. 2020 [9]), Hospital-Acquired infection, Chronic Infection in Cystic Fibrosis patients (Konings et al. 2013) [20], Sepsis Form and Epizootic Enteritis, Febrile Form (Hsiu-Lin Chen et al. 2008) [18]. Indeed, these bacteria can be spread by direct contact with hospital staff, vertical mother-to-child transmission, or ingestion of contaminated material, direct transmission between humans remains widespread (Doran, 1999) [17]. The gut microbiota of an organism is established immediately after birth and changes due to the host life-style, diet, environmental conditions, genome, etc. (Sommer, 2013; Punga and Ifuta, 2015 [2]; Nicholson et al. 2018 [7]). In Canada, for example, Tshape et al. report that an outbreak of Citrobacter infection was associated with the consumption of parsley contaminated with pork purin; 8 urinary tract infections and 1 death were observed (Tschape et al. 1995) [21].

All these enterobacteriaceae in the feces of birds were also found on currency notes (Congolese Francs); in the city of Kinshasa by Iteku and his team, confirming their existence in the environment and precarious hygienic conditions of the region (Iteku et al. 2020) [9].

In 2002, Kurt et al. showed that wild birds can acquire entomopathogens, such as Salmonella and Campylobacter spp., by feeding on raw sewage and garbage, and can transmit these agents directly to humans or by contaminating commercial poultry farms. Conversely, wild birds can acquire drug-resistant entomopathogens on farms and spread these strains along migration routes. Birds contribute to the global spread of emerging infectious diseases in a man-like manner on aircraft. A better understanding of avian migration patterns and infectious 
diseases of birds would be useful in predicting future outbreaks of infections due to new zoonotic pathogens (Kurt et al. 2002) [22].

This study corroborates previous studies that show that wild birds are important to public health because they carry emerging zoonotic pathogens, either as a reservoir host or by dispersing infected arthropod vectors (Kisasa et al. 2020) [3]. Birds have been at the heart of the epidemiology of West Nile virus (WNV) because they are the main amplifying host of the virus in nature, the question remains whether they can also be vectors of coronavirus (covid-19)?

\section{Conclusions}

This study aimed at the determination of pathogenic microorganisms found in the feces of Cattle Egrets and Pied Crows, two species of birds most common in public dumps and in congolese residences, where the focus was on the dumps of student's residences, of the triangle of market gardeners and University Clinics in Kinshasa. The findings showed that most of the microorganisms found in the feces of these birds are from bacterial origin.

By feeding in unsanitary dumps and gutters, birds are parasitized and in turn contaminate humans by defecating on their food or staining cooking utensils. Thus, the population must avoid throwing household waste, sewage, poop and urine in public squares.

In this study, we did only bacteriological analyses. Subsequent studies also report the presence of helminths in the microbiota of some waterfowl. But due to material constraints, we could not identify the species down to the specific level. Therefore, future work will allow the determination of all the microorganisms living on the currency notes. Further studies are required in order to determine if these microorganisms have antibiotic resistance genes. This issue is serious and constitutes a real challenge in the world currently.

Henceforth, evacuating and treating the garbage in Kinshasa, avoiding dumping sewage and other waste in the gutters, urban rivers remain the most effective way of prevention to reduce the contamination of birds and humans by pathogenic microorganisms.

\section{Acknowledgements}

I thank Dr Jean Paul Kote-Te-Nywa Ngbolua for his contribution to improving the form of this paper.

\section{Competing Interests and Ethics}

The authors declare that the research was conducted in the absence of any commercial or financial relationships that could be construed as a potential conflict of interest. However, as an ecologist, we used ecological methods to collect feces without harming the birds (we fed them and then released them afterwards). The field study involving sample collection from birds was approved by the Ethical Committee of the Department of Biology (Faculty of Kinshasa) under 
the registration number N/Ref.005-2020/CE-CDB.

\section{Authors' Contribution}

Robert Kisasa is the project designer and editor of this manuscript. Clarisse Nduaya (my assistant), Chadrak Kafuti, Babby Ekumbo and Michel Ngandu were in charge of catching birds. Cyprien Mbundu is the laboratory technician, he was the one who did the bacteriological analyses assisted by Clarisse Nduaya. Liesse Iyambela is the director of the Experimental and Pharmaceutical Microbiology laboratory. I thank him for establishing a simple protocol for bacteriology analysis of our samples.

\section{Conflicts of Interest}

The authors declare no conflicts of interest regarding the publication of this paper.

\section{References}

[1] Kisasa, K.R. and Aloni, K.J. (2011) The Impact of Soil Texture on the Selection of Nesting Sites by the Malachite Kingfisher (Alcedinidae: Alcedocristata PALLAS 1764). Ostrich Journal, 82, 243-246. https://doi.org/10.2989/00306525.2011.616696

[2] Punga, J.K. and Ifuta, B.N. (2015) Recent Data on Birds of Kinshasa in Democratic Republic of Congo. Journal of Agricultural Science and Technology A, 5, 218-233. https://doi.org/10.17265/2161-6256/2015.03.011

[3] Kisasa, K.R., Banshomire, C. and Malekani, D. (2020) Ectoparasites (Phthiraptera) of Some Birds of Kinshasa City. Malimbus Journal, 42, 1-6.

[4] Djelil, H. (2012) Ectoparasitisme et parasitémie du poulet de ferme (Gallus gallus domesticus, Linnaeus, 1758) dans la région d'Oran. These, Dép. de Biologie, Université d'Oran, Oran.

[5] Amir, A. (2006) Détermination du Microbisme en Élevage Avicole. Thèse, Dép. des Sciences Vétérinaires, Université Mentouri de Constantine, Constantine.

[6] Laviad-Shitrit, S., Izhaki, I., Lalzar, M. and Halpern, M. (2019) Comparative Analysis of Intestine Microbiota of Four Wild Waterbird Species. Frontiers in Microbiology, 10, 1911. https://doi.org/10.3389/fmicb.2019.01911

[7] Nicholson, J.K., Holmes, E., Kinross, J., Burcelin, R., Gibson, G., Jia, W., et al. (2012) Host-Gut Microbiota Metabolic Interactions. Science, 336, 1262-1267. https://doi.org/10.1126/science.1223813

[8] Sommer, F. and Bäckhed, F. (2013) The Gut Microbiota-Masters of Host Development and Physiology. Nature Reviews Microbiology, 11, 227-238. https://doi.org/10.1038/nrmicro2974

[9] Iteku Bekomo, J., Moswala Likabo, D., Lelo Pambu, A., Ngiala Bongo, G., Katunda, R., Metila, L.O. and Kasali, L.J. (2020) Microbiological Analysis and Identification of Pathogenic Microorganisms on Currency Notes (Congolese Francs) in Kinshasa, Democratic Republic of the Congo. Journal of Advances in Microbiology, 20, 16-30. https://doi.org/10.9734/jamb/2020/v20i930278

[10] Ladraa, R. and Kaabouche, A. (2016) Étude microbiologique de la monnaie judicaire Algérienne. Unpublished MSc Dissertation, Speciality on General Micro- 
biology and Molecular Biology of Microorganisms, Department of Microbiology, Faculty of Nature and Life Sciences, Université des frères Mentouri Constantine, Alger, 84.

[11] Benskin, C.W., Wilson, K., Keith, J. and Hartley, I.R. (2009) Bacterial Pathogens in Wild Birds: A Review of the Frequency and Effects of Infection. Biological Reviews, 84, 349-515. https://doi.org/10.1111/j.1469-185X.2008.00076.x

[12] Laudisoit, A., Kisasa, R. and Kidimbu, A. (2005) Les ectoparasites des micromammifères de la ville de Kinshasa: Un facteur de risque pour la santé publique? Colloque sur les recherches scientifiques et Développement de pays africains. ASETIB, Gembloux (Belgique), 151-163.

[13] Hooton, T.M. and Walter Stamm, W.E. (1997) Diagnosis and Treatment of Uncomplicated Urinary Tract Infection. Infectious Disease Clinics, 11, 551-581.

https://doi.org/10.1016/S0891-5520(05)70373-1

[14] Ku, L.C., Boggess, K.A. and Cohen-Wolkowiez, M. (2015) Bacterial Meningitis. Clinics in Perinatology, 42, 29-45. https://doi.org/10.1016/j.clp.2014.10.004

[15] Bryan, C.S. and Reynolds, K. (1984) Hospital-Acquired Bacteremic Urinary Tract Infection: Epidemiology and Outcome. Journal of Urology, 132, 494-497. https://doi.org/10.1016/S0022-5347(17)49707-2

[16] Akihisa, M., Chikao, N., Nobuyasu, E. and Shinkichi, T. (1997) Antibacterial Activity and Mode of Action of Plant Flavonoids against Proteus vulgaris and Staphylococcus aureus. Phytochemistry, 26, 2231-2234.

https://doi.org/10.1016/S0031-9422(00)84689-0

[17] Doran, T.I. (1999) Citrobacter in Clinical Disease of Children: Review Clinical. Clinical Infectious Diseases, 28, 384-394. https://doi.org/10.1086/515106

[18] Chen, H.-L., Hung, C.-H., Tseng, H.-I. and Yang, R.-C. (2008) Soluble Form of Triggering Receptor Expressed on MyeloidCells-1 (sTREM-1) as a Diagnostic Marker of Serious Bacterial Infection in Febrile Infants Less than Three Months of Age. Japanese Journal of Infectious Diseases, 61, 31-35.

[19] Brouwer, M.C., Tunkel, A.R., Mckhan, G.M. and van de Boek, D. (2014) Brain Abscess. The New England Journal of Medicine, 371, 447-456. https://doi.org/10.1056/NEJMra1301635

[20] Konings, A.F., Martin, L.W., Sharples, K.J., Roddam, L.F., Lathan, R., Reid, D.W. and Lamont, I.L. (2013) Pseudomonas aeruginosa Uses Multiple Pathways to Acquire Iron during Chronic Infection in Cystic Fibrosis Lung. Infection and Immunity, 81, 2697-2704. https://doi.org/10.1128/IAI.00418-13

[21] Tschape, H., Prager, R., Streckel, W., Fruth, A., Tietze, E. and Bohme, G. (1995) Verotoxinogenic Citrobacter freundii Associated with Severe Gastroenteritis and Cases of Haemolytic Uraemic Syndrome in a Nursery School: Green Butter as the Infection Source. Epidemiology and Infection, 114, 441-450. https://doi.org/10.1017/S0950268800052158

[22] Reed, K.D., Meece, J.K. and Shukla, W.S.K. (2002) Birds, Migration and Emerging Zoonoses: West Nile Virus, Lyme Disease, Influenza A and Enteropathogens. Clinical Medicine and Research, 1, 5-12. https://doi.org/10.3121/cmr.1.1.5 